\title{
Pharmacognostic study of the leaf of Ageratina adenophora
}

\author{
Nungshioba Jamir, Muslek Uddin Mazumder, P. Khazeo, K. Nusalu Puro, Rosamund Jyrwa, \\ Lalzikpuii Sailo*
}

Department of Pharmacy, Regional Institute of Paramedical and Nursing Sciences, Zemabawk 796017, Mizoram, India

Corresponding author: zikpuii08@gmail.com

\begin{abstract}
Ageratina adenophora (Asteraceae), commonly known as Crofton weed or sticky snakeroot, leaves are used for various health conditions in traditional medicines. They are used for treatment such as wound, itching, measles, skin diseases, uterine bleeding and also acts as antibacterial and astringent activity. Macroscopic and quantitative microscopic methods were applied to determine the diagnostic features for the identification and standardization of the fresh leaf samples of $\mathbf{A}$ adenophora. Macroscopically, the leaves were found to have an opposite trowel-shaped serration that are 6-10 cm long by 3-6 cm in width. They have a mild characteristic smell and bitter in taste. They are dark-green in colour, while the stems are reddish in colour. The flowers are creamy white coloured followed by a small brown seed with a white feathery parachute. The light and electron microscope images of cross-section of leaf revealed useful diagnostic features. They have anomocytic type of stomata. The stomatal number, stomatal index, vein islet and vein termination number were determined. In the transverse section of the leaf, collenchyma cells, parenchyma cells, vascular bundles, trichomes, palisade cells, upper and lower epidermis were observed. These findings are helpful in authentication of $\mathbf{A}$ adenophora, as well as in laying down its pharmacopoeial standards.
\end{abstract}

Keywords: Microscopy, Macroscopy, Crofton leaf, transverse section, anomocytic stomata.

\section{INTRODUCTION}

New drug discoveries through natural products have proved to be very vital and effective approach (Ravinder et al., 2018). Over decades, different cultures all over the world have learned to use natural products as traditional medicine to treat ailments and diseases and identified natural product have the ability to give new drugs (Kunle et al., 2012). India provides huge biodiversity in flora and fauna which have important therapeutic values. Though with the advancement in pharmaceutical technology in modern medicine, huge number of people still uses traditional medicine from various sources which includes plants and animals (Balamurugan et al., 2009).

Huge amount of natural products having medicinal value or therapeutic potential are not yet discovered or scientifically undertaken. Hence, this makes pharmacognostic studies important (Dhanbal et al., 2005). Due to the rise of demand in use of natural products as medicine, there is an increased use of adulterated and spurious drugs or inferior quality drugs. Therefore, purity and quality assessment becomes an essential factor and standardization becomes vital for the safety of the herbal drugs. The present study is carried out with the objective to identify and provide a pharmagonostic standard of the plant Ageratina adenophora (Ravinder et al., 2018).

A. adenophora commonly known as crofton weed, sticky snakeroot, Mexican devil, cat weed or eupatory, is a perennial herbaceous plant which is native to Mexico. It is a very aggressive invasive plant species known in most part the world. It belongs to the family Asteraceae (Compositae) (Auld, 1970). Its synonyms are Ageratina trapezoidea (Kunth), Eupatorium adenophorum Spreng., E. glandulosum Kunth, non Michx., E. pasdadense Parish, E. trapezoideum Kunth (Muniappan et al., 2014). 


\section{MATERIALS AND METHODS}

\section{Collection and authentication of the plant}

The whole plant of the plant $A$. adenophora were collected from the campus of Regional Institute of Paramedical and Nursing Sciences, Aizawl, Mizoram, India. The plant was authenticated by a taxonomist at the Botanical Survey of India, Eastern Regional Centre, Shillong. A voucher specimen was deposited in the Department of Pharmacy, RIPANS, with reference no: BSI/ERC/TECH/ Plant Iden./2018/136

\section{Macroscopic analysis}

Macroscopic analysis was done by studying the shape and size, colour, odour, taste, surface, characters, texture, the apex, margin, and base (Kokate et al., 2005).

\section{Microscopic analysis}

Transverse section of leaf

Microscopic analysis of the plant $A$. adenophora was carried out by cutting the transverse section of the leaf including the lamina and the midrib which was treated with phloroglucinol hydrochloride solution. It was mounted with glycerine on a glass-slide and observed under projection microscope at 10X. The images were captured and its diagnostic characteristic features were recorded.

\section{Quantitative microscopy}

Quantitative analysis of leaf microscopy was performed to determine the stomatal index, stomatal number, vein termination number and vein islet number (Kokate, 1994).

\section{Determination of stomatal number}

Upper and lower epidermal layers of the leaf was freshly prepared for the analysis. The specimen peels were prepared manually using forceps which was mounted on a glass slide with glycerin (Sumitra et al., 2009). The prepared sample was observed under projection microscope (Primo Star, Zeiss) at 10X. The number of stomata present in $600 \mu \mathrm{m}$ square were counted and recorded in four different fields. The mean value was taken.

\section{Determination of stomatal index}

Upper and lower epidermal layers of the leaf was freshly prepared for the analysis. The specimen peels were prepared manually using forceps which was mounted on a glass slide with glycerin (Sumitra et al.,
2009). The prepared sample slide was observed under Projection microscope at 10X. The number of stomata and epidermal cells present were counted in four different fields. Then, the mean value was taken and stomatal index (I) was calculated by using the formula,

$$
I=S \times 100 / E+S
$$

Determination of vein-islet and vein-termination number

Fresh leaves were boiled in chloral hydrate solution in a clean beaker on water bath for 3-5 hours. Then, the sample was mounted on a glass-slide and observed under Projection microscope at 10X. The numbers of veinislet and vein-termination present were counted and recorded in four different fields. An area of $60 \times 60 \mathrm{~mm}$ square were considered for observations and the mean value was calculated to find the result.

\section{RESULTS}

Pharmacognostic studies of the plant $A$. adenophora were performed and the following results were found.

\section{Macroscopic character}

Habitat: A.adenophora Linn is a perennial herbaceous plant which grows to a height of $1-3 \mathrm{~m}$ in height. It is erect and has a stem of woody root-stock.

Leaves: The plant was found to have opposite trowel -shaped serrated leaves that are $6-10 \mathrm{~cm}$ in length and 3 $6 \mathrm{~cm}$ in width. The leaves are dark green in colour which is smooth in texture and the stems were reddish in colour (Figure 1). It has a mild characteristic smell and is bitter in taste.

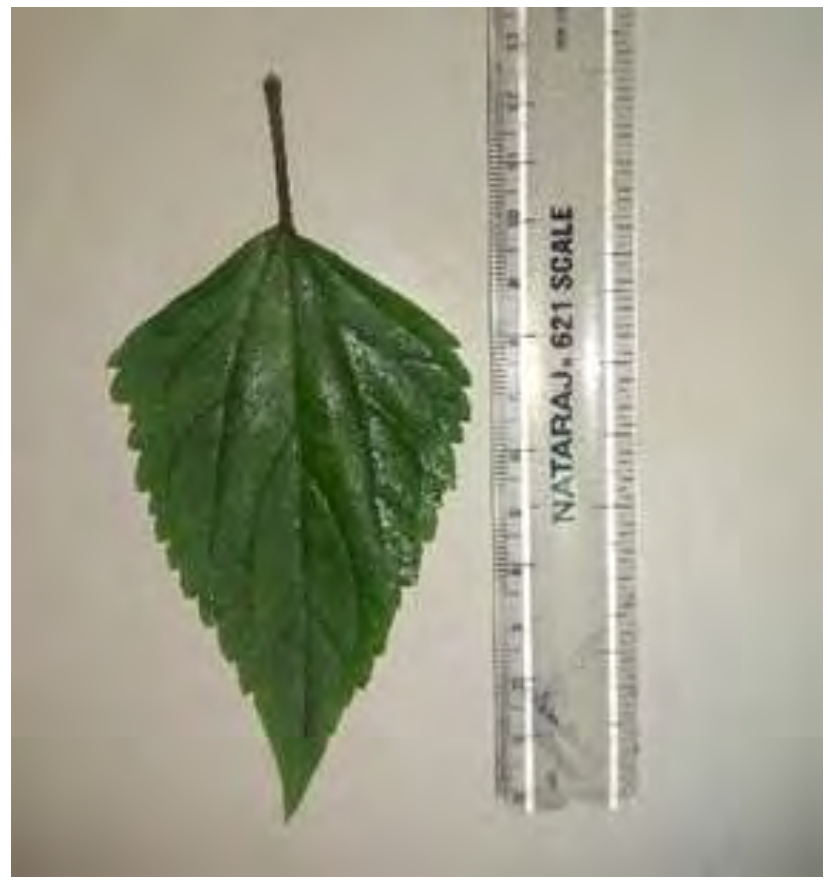

Figure 1: Leaf of Ageratina adenophora. 


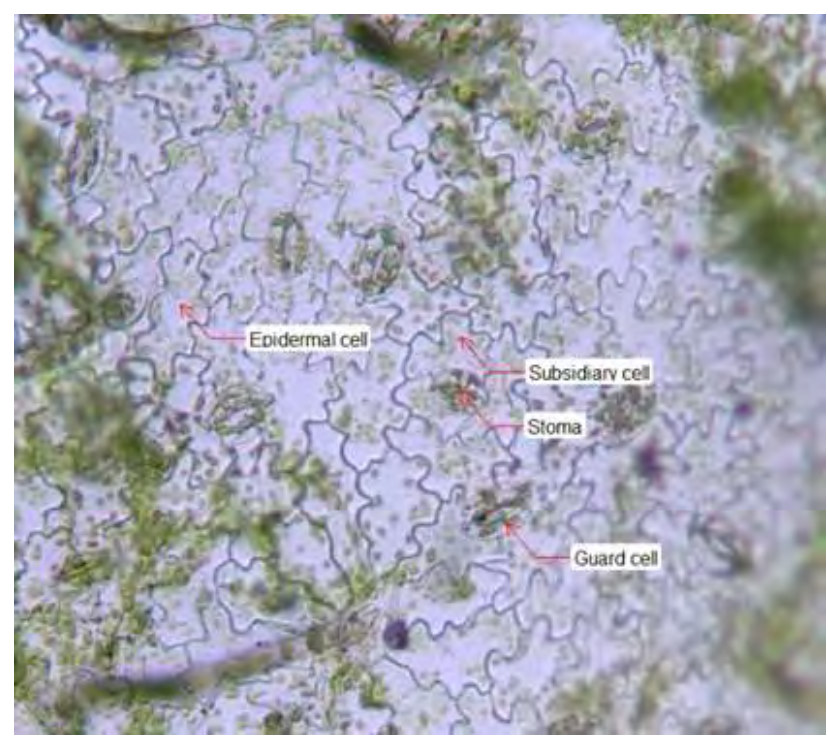

Figure 2: Anomocytic type of stomata was observed in the leaves of A. adenophora.

\section{Microscopic characters}

Figure 2 shows the tissue structure of the leaf of $A$. adenophora indicating anomocytic type of stomata. Transverse section of leaf in Figure 3 showed the presence of vascular bundles (xylem and phloem), parenchyma cells, collenchyma cells, trichome, palisade cells, upper and lower epidermis.

\section{Quantitative microscopy of the leaf}

The quantitative microscopic characters of the leaf of $A$. adenophora was determined and results were shown in Table 1.

\section{DISCUSSION}

The results obtained from the study will be useful in finding out the genuine potential of $A$. adenophora as a
Table 1: Quantitative microscopic characters of the leaf of $A$. adenophora.

\begin{tabular}{|l|c|}
\hline \multicolumn{1}{|c|}{ Parameters } & Range \\
\hline Stomatal number (lower epidermis) & $3.25 \pm 0.95$ \\
\hline Stomatal number (upper epidermis) & $1.1 \pm 0.25$ \\
\hline Stomatal index (lower epidermis) & $37.5 \pm 0.85$ \\
\hline Stomatal index (upper epidermis) & $16.66 \pm 1.02$ \\
\hline Vein-islet number & $3 \pm 1$ \\
\hline Vein-termination number & $3.25 \pm 0.5$ \\
\hline
\end{tabular}

source of crude drug. It can also be used as a reliable source for detecting adulterations. This simple but reliable standard will be helpful in the identification and selection of the raw material for drug production. The plant was found to have opposite trowel-shaped serrated leaves that are $6-10 \mathrm{~cm}$ in length and 3-6 cm in width. The leaves are dark green in colour which is smooth in texture and the stems were reddish in colour as shown in Figure 1. It has a mild characteristic smell and is bitter in taste.

The microscopic study revealed the presence of epidermal cell, subsidiary cell, stoma and guard cell (Figure 2). It was also found out the leaf contains anomocytic type of stomata. The transverse section of leaf observed under projection microscope showed the presence of vascular bundles (xylem and phloem), parenchyma cells, collenchyma cells, trichome, palisade cells, upper and lower epidermis (Figure 3). Under the quantitative microscopic characters of the leaf of $A$. adenophora (Table 1 ). It was recorded and found the stomatal number (lower epidermis) to be under the range $3.25 \pm 0.95$; but the stomatal number (upper epidermis) was found under the range $1.1 \pm 0.25$. Stomatal index (lower epidermis) was found under the range $3.75 \pm 0.85$, while stomatal index (upper epidermis) was found under the range $16.66 \pm 1.02$. Vein-islet number was found under the range $3 \pm 1$ and vein-termination number a was found under the range $3.25 \pm 0.5$.

The result of the study serves as a valuable source of information and also provide suitable standards for identification of this plant material for future investigations.
Figure 3: Transverse section of leaf showed the presence of vascular bundles (xylem and phloem), parenchyma cells, collenchyma cells, trichome, palisade cells, upper and lower epidermis.

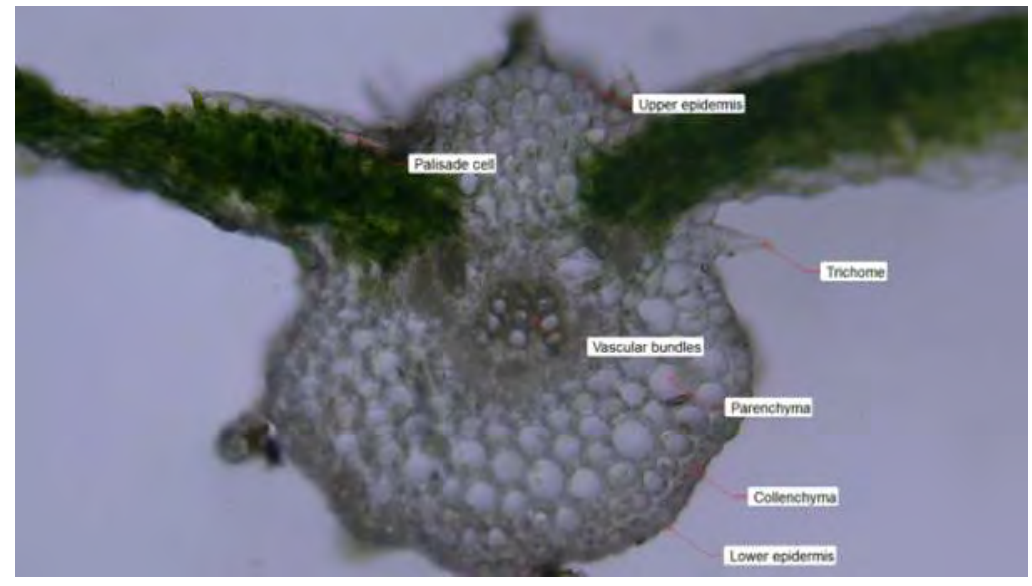




\section{ACKNOWLEDGEMENT}

We the Authors would like to express our heartfelt gratitude and sincere thanks to Dr. Chawngthanliana, Director, RIPANS, for giving us the privilege to undertake this project. We extend our deepest gratitude to Dr. $\mathrm{H}$. Lalhlenmawia, Head of the Department of Pharmacy, for allowing to utilize the facilities to conduct this study. And also extend gratitude to Dr. A.A. Mao, Scientist-F \& Head of office, Botanical Survey of India (BSI), Shillong, for identification and authentication of the plant species.

\section{REFERENCES}

Alvarez, M. (2000). Ageratina adenophora. In: Bossard CC, Randall JM, Hoshovsky MC Invasive Plants of California's Wildlands. University of California Press, Berkeley, CA, pp. 29-187.

Auld, B.A. (1970). Eupatorium weed species in Australia. PANS, 16: 82-86.

Auld, B. A., Martin, P. M. (1975). The autecology of Eupatorium adenophorum Spreng. in Australia. Weed Research, 15(1): 27-31.

Balamurugan, M., Parthasarathi, K., Cooper, E. L., Ranganathan, L. S. (2009). Anti-inflammatory and antipyretic activities of earthworm extract-Lampito mauritii (Kinberg). Journal of Ethnopharmacology, 121(2): 330-332.
CABI (2013), Ageratina adenophora. In: Invasive Species Compendium. CAB International, Wallingford, UK. Available: www.cabi.org/isc.

Dhanaba, S.P., Suresh, B., Sheejat, E., Edwin, E. (2005), Pharmacognostical studies on Passiflora quandrangularis. Indian Journal of Natural Products, 21(1): 9-11.

Janarthanan, L., Karthikeyan, V., Jaykar, B., Senthilkumar, K.L., Anandharaj, G. (2016). Pharmacognostic studies on the whole plants of Ageratum conyzoides Linn. (Asteraceae). European Journal of Pharmaceutical and Medical Research, 3(5): 618-626.

Kokate, C.K. (1994). Practical Pharmacognosy. Delhi: Vallabh Prakashan, pp. 107-111.

Kokate, C.K., Purohit, A.P., Gokhale, S.B. (2008). Textbook of Pharmacognosy. Nirali Prakashan, Pune, pp. A1-A6.

Kunle, O.F., Egharevba, H.O., Ahmadu, P.O. (2012). Standardization of herbal medicines-A review. International Journal of Biodiversity and Conservation, 4(3): 101-112.

Ravinder, K., Balbir, S., Sarajit, K. (2018). Pharmacognostic studies on leaves of Ageratum conyzoides Linn. Journal of Pharmacognosy and Phytochemistry, 7(3): 3181-3185.

Rundall, P.J. (2007) Anatomy of Flowering Plant: An Introduction to Structure and Development ( $3^{\text {rd }}$ edition). Cambridge University PRESS, New York, pp. 13-84. 